\title{
Tracing carbon flow through coral reef food webs using a compound-specific stable isotope approach
}

\author{
Kelton W. McMahon ${ }^{1,2,3} \cdot$ Simon R. Thorrold $^{2} \cdot$ Leah A. Houghton ${ }^{2} \cdot$ \\ Michael L. Berumen ${ }^{1}$
}

Received: 26 January 2015 / Accepted: 4 October 2015

(C) Springer-Verlag Berlin Heidelberg 2015

\begin{abstract}
Coral reefs support spectacularly productive and diverse communities in tropical and sub-tropical waters throughout the world's oceans. Debate continues, however, on the degree to which reef biomass is supported by new water column production, benthic primary production, and recycled detrital carbon (C). We coupled compound-specific stable $\mathrm{C}$ isotope ratio $\left(\delta^{13} \mathrm{C}\right)$ analyses with Bayesian mixing models to quantify $\mathrm{C}$ flow from primary producers to coral reef fishes across multiple feeding guilds and trophic positions in the Red Sea. Analyses of reef fishes with putative diets composed primarily of zooplankton (Amblyglyphidodon indicus), benthic macroalgae (Stegastes nigricans), reef-associated detritus (Ctenochaetus striatus), and coral tissue (Chaetodon trifascialis) confirmed that ${ }^{13} \mathrm{C}$ values of essential amino acids from all baseline $\mathrm{C}$ sources were both isotopically diagnostic and accurately recorded in consumer tissues. While all four source endmembers contributed to the production of coral reef fishes in our study, a single-source end-member often dominated
\end{abstract}

Communicated by Deron E. Burkepile.

Electronic supplementary material The online version of this article (doi:10.1007/s00442-015-3475-3) contains supplementary material, which is available to authorized users.

Kelton W. McMahon

kemcmaho@ucsc.edu

1 Division of Biological and Environmental Science and Engineering, Red Sea Research Center, King Abdullah University of Science and Technology, Thuwal 23955, Saudi Arabia

2 Biology Department, Woods Hole Oceanographic Institution, Woods Hole, MA 02543, USA

3 Institute of Marine Sciences, University of California, Santa Cruz, Santa Cruz, CA 95064, USA dietary $\mathrm{C}$ assimilation of a given species, even for highly mobile, generalist top predators. Microbially reworked detritus was an important secondary $\mathrm{C}$ source for most species. Seascape configuration played an important role in structuring resource utilization patterns. For instance, Lutjanus ehrenbergii showed a significant shift from a benthic macroalgal food web on shelf reefs $(71 \pm 13 \%$ of dietary C) to a phytoplankton-based food web $(72 \pm 11 \%)$ on oceanic reefs. Our work provides insights into the roles that diverse $\mathrm{C}$ sources play in the structure and function of coral reef ecosystems and illustrates a powerful fingerprinting method to develop and test nutritional frameworks for understanding resource utilization.

Keywords Amino acids - Bayesian mixing model - Diet · Fish $\cdot$ Red Sea

\section{Introduction}

Coral reefs represent some of the most productive and biologically diverse ecosystems on Earth (Odum and Odum 1955; Ryther 1969; Connell 1978; Hughes et al. 2002). Yet this observation remains enigmatic given that many coral reefs occur at latitudes characterized by significant nutrient limitation (Muscatine 1973; Hallock and Schlager 1986). More than a century ago, Darwin (1842) posed the question of how coral reefs were so productive and diverse in oligotrophic ocean waters-a question that we have yet to satisfactorily answer. One hypothesis proposes that reef-associated planktivores act as a "wall of mouth" that captures significant amounts of carbon (C) fixed in the water column by phytoplankton (Emery 1973; Hamner et al. 1988; Genin et al. 2009; Wyatt et al. 2010). Other ideas have linked high productivity on coral reefs to mechanisms that efficiently 
recycle $\mathrm{C}$ and nutrients within the system, through symbioses (Muscatine and Porter 1977; Cowen 1988), remineralization pathways (Richter et al. 2001; Wild et al. 2004; Wyatt et al. 2012a; de Goeij et al. 2013), and microbially reworked detrital pathways (Alongi et al. 1988; Gast et al. 1998; Ferrier-Pages and Gattuso 1998). Distinguishing among these competing hypotheses is important to understanding the mechanisms that underlie coral reef function and resilience as well as the species responsible for maintaining these processes in the face of global climate change and anthropogenic disturbance (Pandolfi et al. 2003; Cote et al. 2005; Hughes et al. 2007).

The structure and function of coral reefs are intricately tied to the sources and pathways of $\mathrm{C}$ flow through reef food webs (Lindeman 1942; Moore et al. 2004). However, accurate estimates of $\mathrm{C}$ flow are challenging to obtain in systems characterized by complex food webs. Stable isotope analysis (SIA) provides a method for tracing C flow that avoids many of the challenges associated with constructing food webs from conventional gut content analysis and feeding observations (Deb 1997; Bearhop et al. 2004). However, coral reefs remain challenging systems to examine with SIA due to difficulties characterizing multiple end-members at the base of the food web (hereafter "source end-members") and interpreting shifts in diet, trophic position, and baseline stable $\mathrm{C}$ isotope ratio values $\left(\delta^{13} C_{\text {baseline}}\right)$ in highly dynamic systems (Post 2002). Bulk SIA has, therefore, seen limited use in coral reef systems, with most studies either forced to rely on trends of increasing $\delta^{15} \mathrm{~N}$ values and decreasing $\delta^{13} \mathrm{C}$ values as indicative of increased reliance on oceanic productivity, or suffering from under-determined mixing models and uncertainty regarding trophic fractionation in complex food webs (Carassou et al. 2008; Greenwood et al. 2010; Wyatt et al. 2012b; Hilting et al. 2013; Letourneur et al. 2013).

Recent work has highlighted opportunities to enhance studies of $\mathrm{C}$ flow in ocean environments by analyzing $\delta^{13} \mathrm{C}$ values of specific biochemical compounds, particularly amino acids (AAs) (reviewed in McMahon et al. 2013). Metabolic diversity in essential AA synthesis pathways and isotope effects generates unique isotopic signatures or "fingerprints" among diverse source end-members (Hayes 2001; Scott et al. 2006; Larsen et al. 2009, 2013) that are robust to many of the factors affecting bulk $\delta^{13} \mathrm{C}$ values (Larsen et al. 2015). While primary producers and bacteria can synthesize essential AAs de novo, most animals do not possess the necessary enzymatic pathways to synthesize these AAs at a rate sufficient for normal growth (Borman et al. 1946; Reeds 2000) and therefore must incorporate essential AAs directly from their diet with minimal trophic fractionation (Hare et al. 1991; Howland et al. 2003; Jim et al. 2006; McMahon et al. 2010). Essential AA $\delta^{13} \mathrm{C}$ signatures propagate through food webs virtually unmodified
(Arthur et al. 2014; Schiff et al. 2014; McMahon et al. 2015), which avoids the complications of variable and poorly characterized trophic fractionation factors in mixing models (Bond and Diamond 2011). Furthermore, this compound-specific SIA (CSIA) approach typically provides five or more essential AAs with independent synthesis pathways in a single analysis, allowing for better constraint of source end-member signatures while avoiding the biases common to under-determined mixing models using poorly resolved dual-isotope approaches in systems with multiple end-members (Fry 2013; Brett 2014).

In this study we coupled CSIA with a Bayesian isotope mixing-model approach to determine the sources of $\mathrm{C}$ assimilated by seven species of coral reef fishes spanning a wide range of feeding guilds and trophic positions on Saudi Arabian reefs in the Red Sea. We initially determined if $\delta^{13} \mathrm{C}$ values in essential AAs differed among four distinct end-members (phytoplankton, benthic macroalgae, corals, and detritus) and between reef locations. We then addressed the following specific questions:

1. Which $\mathrm{C}$ sources supported our focal reef fish species?

2. Does $\mathrm{C}$ source use vary spatially between shelf and oceanic reefs?

Earlier studies by Emery (1973) and Hamner et al. (1988) hypothesized that water column production contributed significantly to the $\mathrm{C}$ sequestered in fish biomass on coral reefs, while more recent studies have suggested recycling pathways may play significant roles in reef production (Richter et al. 2001; Wild et al. 2004; de Goeij et al. 2013). As reefs globally face increasing pressures from climate change and anthropogenic disturbances (e.g., Polovina 1984; Arias-Gonzalez et al. 2004; Hilting et al. 2013), understanding $C$ flow in reef systems will become even more important to their long-term conservation and management.

\section{Materials and methods}

\section{Study site}

We sampled four source end-members (96 samples total) and seven coral reef fish species (260 samples total) from isolated coral reefs located on the continental shelf (shelf reefs, $n=4$ ) and in oceanic waters beyond the shelf (oceanic reefs, $n=4)$ near Al-Lith on the Saudi Arabian coast of the Red Sea in March 2009 and June 2010 (Fig. 1). Shelf reefs were situated on the continental shelf in water not exceeding $60 \mathrm{~m}$ depth. Shelf reefs were characterized by water with visibility usually less than $25 \mathrm{~m}$. Conversely, the oceanic reefs were steep-walled pinnacles rising rapidly 
Fig. 1 Map of the collection sites for source end-members and fish species from shelf reefs (triangles) located on the continental shelf and oceanic reefs (circles) located off the continental shelf and surrounded by deep open water (four reefs per location) near Al-Lith (star in inset), Saudi Arabia in the Red Sea. Contour lines indicate $25-\mathrm{m}$ isobaths

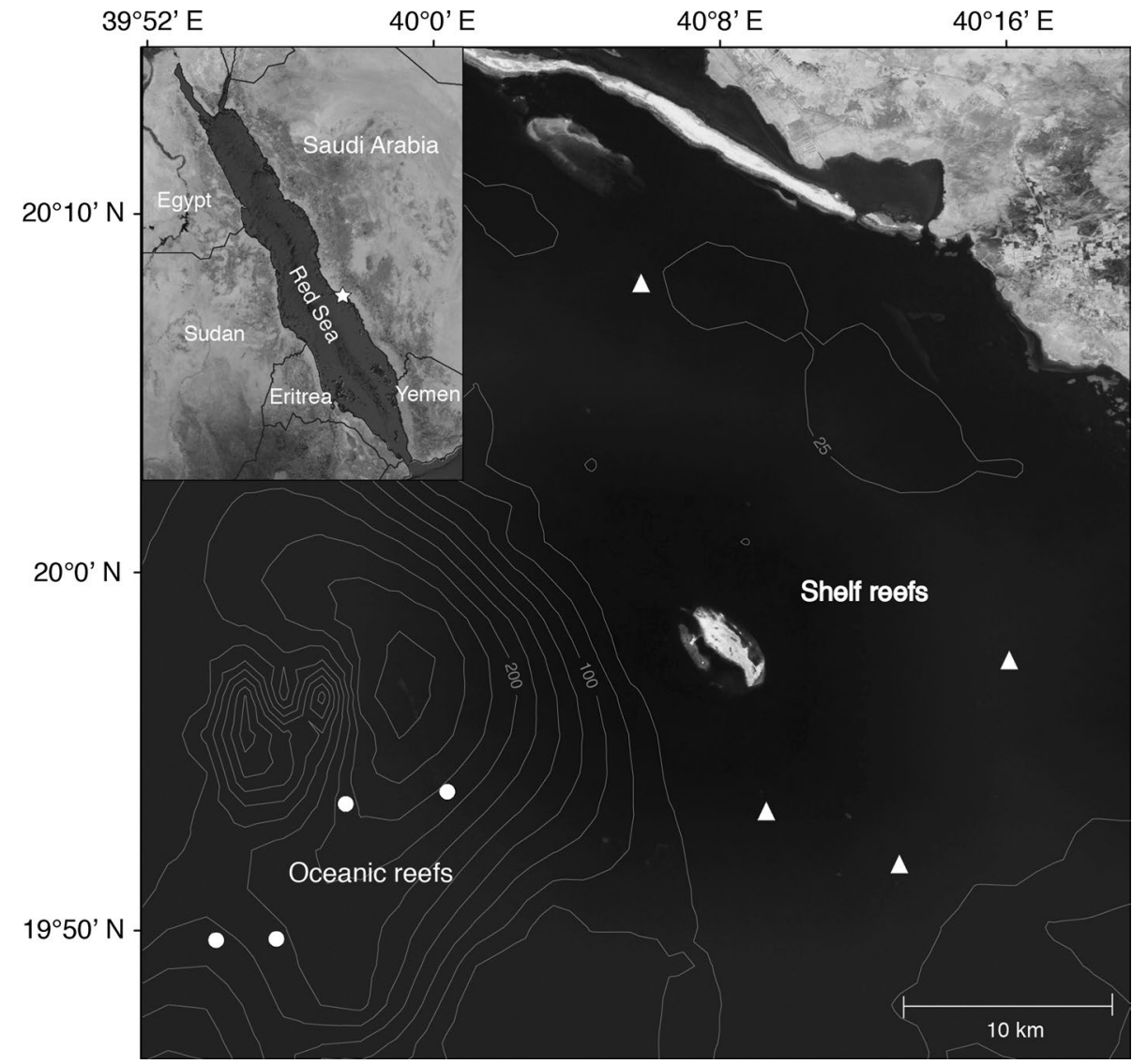

from deep water $(>300 \mathrm{~m}$ ) with visibility often exceeding $40 \mathrm{~m}$. Saudi reefs in the Red Sea are characterized by relatively little structural complexity at the habitat level (Shepard and Shepard 1991), and none of our study reefs had lagoon or back-reef environments.

We characterized $\mathrm{C}$ isotope signatures of four distinct source end-members at the base of the food web on each reef: phytoplankton, macroalgae, coral, and detritus. We collected calanoid copepods that feed on phytoplankton, dinoflagellates, and protists within pelagic food webs (e.g., Kleppel 1993) using a 1-m-diameter, 333- $\mu$ m-mesh net towed in the water column around the perimeter of each reef ( $n=3$ tows/reef). Given that essential AAs show virtually no fractionation between diet and consumer (McMahon et al. 2010, 2013), the essential AA $\delta^{13} \mathrm{C}$ values of pelagic copepods provided a faithful proxy for pelagic phytoplankton. We collected a filamentous macroalga (Womersleyella setacea) that is farmed by the dusky farmerfish (Stegastes nigricans, Lacepede 1802) (Hata and Kato 2002) from each reef ( $n=3$ sites collected throughout each reef). We selected a species of staghorn coral, Acropora pharaonis, that is targeted by corallivores (e.g., Berumen and Pratchett 2008) to represent $\mathrm{C}$ fixed by autotrophic zooxanthellae and heterotrophic feeding by corals $(n=3$ coral tables collected throughout each reef). Given the challenges in isolating the detrital end-member, we selected the detritivorous black sea cucumber, Holothuria atra, as a proxy for detritus (Moriarty 1982; Uthicke 1999) ( $n=3$ individuals collected throughout each reef).

We collected adult individuals from seven species of reef fishes, representing a suite of feeding guilds from detritivores to top predators. There were no significant differences in total length between individuals collected on shelf and oceanic reefs for any species (Online Resource 1). Feeding ecology of each species was classified according to Sommer et al. (1996) and Lieske and Myers (2004). Lined bristletooths, Ctenochaetus striatus (Quoy and Gaimard 1825), are common detritivorous surgeonfish that typically ingest sediments to target detritus, blue-green algae, and benthic diatoms. Bullethead parrotfish, Chlorurus sordidus (Forsskål 1775), feed on benthic algae and detritus. We sampled two species of damselfish that occupy different feeding guilds. Pale damselfish, Amblyglyphidodon indicus (Allen and Randall 2002), feed primarily on zooplankton, while dusky farmerfish, $S$. nigricans, feed almost exclusively on farmed filamentous macroalgae, such as W. setacea. Chevron butterflyfish, Chaetodon trifascialis (Quoy and Gaimard 1825), are obligate corallivores that feed on the polyps and mucus 
of corals, most commonly in the genus Acropora. Ehrenberg's snapper, Lutjanus ehrenbergii (Peters 1869), are mesopredators that feed primarily on benthic invertebrates and small fishes. Giant moray eels, Gymnothorax javanicus (Bleeker 1859), were selected as resident top piscivores at each reef. Due to the small size of the reefs, we were able to effectively sample individuals from the entire perimeter of each reef ( $n=5$ individuals/reef, except $G$. javanicus where two or three individuals were collected per reef).

\section{Sample preparation and analysis}

Several calanoid copepods were isolated from each plankton tow and then homogenized. Macroalgae samples were cleaned of epizoic fauna and homogenized. Coral tissue was removed from the skeleton with an air pick and represented a consortium of coral tissue, coral mucus, and the associated microbial community. For the detritus endmember, we used homogenized dermal tissue from H. atra. Moray eels were captured in baited fish traps and biopsied with a small hand biopsy tool, while the remaining fish species were collected by speargun. White muscle samples from all individual fishes were frozen on the boat and transported to an on-shore laboratory for further processing. Samples were frozen at $-20{ }^{\circ} \mathrm{C}$ and then lyophilized (freeze-dried) for $48 \mathrm{~h}$ prior to homogenization with a mortar and pestle.

We acid hydrolyzed and derivatized samples prior to CSIA according to McMahon et al. (2011). Briefly, each sample underwent an acid-catalyzed esterification followed by acylation with trifluoroacetic anhydride and dichloromethane under an atmosphere of dinitrogen $\left(\mathrm{N}_{2}\right)$. Samples were brought up in dichloromethane and injected on a column in splitless mode at $260{ }^{\circ} \mathrm{C}$ and separated on a forte SolGel-1 ms column (60 m length, $0.25 \mathrm{~mm}$ inner diameter, and $0.25 \mu \mathrm{m}$ film thickness; SGE Analytical Science, Sydney) in a Agilent $6890 \mathrm{~N}$ gas chromatograph at the Woods Hole Oceanographic Institution (Woods Hole, MA). The separated AA peaks were combusted online in a Finnigan gas chromatography-combustion continuous flow interface at $1030{ }^{\circ} \mathrm{C}$, then measured as $\mathrm{CO}_{2}$ on a Thermo Finnigan Mat 253 isotope ratio monitoring mass spectrometer. Standardization of runs was achieved using intermittent pulses of a $\mathrm{CO}_{2}$ reference gas of known isotopic composition. All CSIA samples were analyzed in duplicate along with AA standards of known isotopic composition from Sigma-Aldrich (mean reproducibility for all individual standard AAs was $\pm 0.2 \%$ ) to correct for the introduction of exogenous $\mathrm{C}$ and kinetic fractionation associated with derivitization (Silfer et al. 1991). We focused on five essential AAs (threonine, isoleucine, valine, phenylalanine, and leucine) with sufficient peak size and baseline gas chromatography separation for accurate CSIA (mean reproducibility for all individuals AAs from a long-term lab fish muscle standard was $\pm 0.6 \%$ ).

\section{Data analysis}

We characterized unique isotope signatures for the four source end-members on shelf and oceanic reefs based on the $\delta^{13} \mathrm{C}$ values of five essential AAs; threonine, valine, isoleucine, phenylalanine, and leucine. We tested for variations in the $\delta^{13} \mathrm{C}$ values of individual essential AAs using a mixed-model ANOVA with end-member $(n=4)$ and location (shelf or oceanic) as fixed factors and reefs nested within location as a random factor. Tukey's honest significant difference tests were used for multiple pairwise comparisons of significant effects identified by the ANOVAs. We then visualized the multivariate signatures of essential AA $\delta^{13} \mathrm{C}$ values from source end-members and reef fish species with principal component analysis (PCA) using the covariance matrix.

To quantify the relative contributions of the four source end-members to the seven fish species on shelf and oceanic reefs, we used a fully Bayesian stable isotope mixing-model approach (sensu Ward et al. 2010) within the Stable Isotope Analysis in R (SIAR) package, version 3.0.2 (Parnell et al. 2010; R Development Core Team 2013). We used the $\delta^{13} \mathrm{C}$ values of five essential AAs (threonine, isoleucine, valine, phenylalanine, and leucine) to identify unique isotopic signatures for each source end-member on each reef $(n=3$ samples/end-member per reef). We used a small non-zero trophic discrimination factor in the model $(0.1 \pm 0.1 \%)$ that reflected the minimal trophic fractionation of essential AAs between diet and consumer (McMahon et al. 2010). For the consumer data, we used essential AA $\delta^{13} \mathrm{C}$ values from individual samples. We conducted separate models for each species and reef using reef specific end-member essential AA $\delta^{13} \mathrm{C}$ values with the siarsolomemcv4 function within SIAR (500,000 iterations and an initial discard of the first 50,000 iterations as burn-in). We tested for differences in the relative contribution of the dominant source end-member between shelf and oceanic locations for each species with two-sample $t$-tests ( $n=20$ individuals/location).

The resulting data (proportions of each of the four endmembers) were used to examine variability in $C$ source use among focal species and across the seascape. We used a multivariate cluster analysis framework to visualize associations among individual samples and their respective endmember compositions. A $k$-means strategy identified the most parsimonious number of clusters within the multivariate data set, and then a constellation plot visualized sample associations within these clusters. All univariate, PCA, and cluster analyses were performed in the JMP statistical environment, version 11 (JMP 2013). 
Table 1 Results from a mixed-model ANOVA to test for variations in source endmember $(E M)$ stable carbon $(\mathrm{C})$ isotope ratio $\left(\delta^{13} \mathrm{C}\right)$ values of five essential amino acids $(A A s)$ on Red Sea reefs

\begin{tabular}{|c|c|c|c|c|c|c|}
\hline AAs & Source & SS & MS & $d f$ & $F$-ratio & $P<F$ \\
\hline \multirow[t]{4}{*}{ Threonine } & Loc. & 11.3 & 11.3 & 1,6 & 10.6 & 0.017 \\
\hline & EM & 367.9 & 122.6 & 3,18 & 111.6 & $<0.0001$ \\
\hline & Loc. $\times$ EM & 5.6 & 1.86 & 3,18 & 1.7 & 0.203 \\
\hline & Reef(Loc.) & 6.4 & 1.05 & 6,18 & 0.96 & 0.477 \\
\hline \multirow[t]{4}{*}{ Isoleucine } & Loc. & 0.09 & 0.09 & 1,6 & 0.07 & 0.799 \\
\hline & EM & 215.6 & 71.6 & 3,18 & 53.6 & $<0.0001$ \\
\hline & Loc. $\times$ EM & 21.1 & 7.0 & 3,18 & 5.2 & 0.009 \\
\hline & Reef(Loc.) & 7.9 & 1.3 & 6,18 & 1.0 & 0.469 \\
\hline \multirow[t]{4}{*}{ Valine } & Loc. & 4.8 & 4.8 & 1,6 & 6.4 & 0.045 \\
\hline & EM & 392.0 & 130.7 & 3,18 & 246.2 & $<0.0001$ \\
\hline & Loc. $\times$ EM & 16.1 & 5.4 & 3,18 & 10.1 & 0.0004 \\
\hline & Reef(Loc.) & 4.5 & 0.75 & 6,18 & 1.4 & 0.26 \\
\hline \multirow[t]{4}{*}{ Phenylalanine } & Loc. & 2.1 & 2.1 & 1,6 & 1.6 & 0.254 \\
\hline & EM & 194.0 & 64.7 & 3,18 & 60.4 & $<0.0001$ \\
\hline & Loc. $\times$ EM & 2.1 & 0.7 & 3,18 & 0.7 & 0.59 \\
\hline & Reef(Loc.) & 7.9 & 1.3 & 6,18 & 1.2 & 0.34 \\
\hline \multirow[t]{4}{*}{ Leucine } & Loc. & 0.9 & 0.9 & 1,6 & 0.5 & 0.487 \\
\hline & EM & 441.2 & 147.1 & 3,18 & 196.9 & $<0.0001$ \\
\hline & Loc. $\times$ EM & 6.3 & 2.1 & 3,18 & 2.8 & 0.069 \\
\hline & Reef(Loc.) & 10.4 & 1.7 & 6,18 & 2.3 & 0.077 \\
\hline
\end{tabular}

EM (plankton, macroalgae, coral, detritus) and location (Loc.; shelf, oceanic) were fixed factors, while reef $(n=4)$ nested within Loc. was a random factor

$P$ values in italic significant at $\alpha 0.05$

\section{Results}

We quantified $\delta^{13} \mathrm{C}$ values of five essential AAs from a total of 96 end-member samples and 260 fish muscle samples from our eight study reefs (Online Resource 2). Using separate mixed-model univariate ANOVAs of source endmember $\delta^{13} \mathrm{C}$ values for each essential AA, we found a significant location $\times$ end-member interaction for valine only (Table 1). Location effects were identified for threonine and valine, while end-members differed significantly for all essential AA values. For threonine and isoleucine, the coral end-member differed significantly from that of detritus, which was in turn significantly different from those of phytoplankton and macroalgae (Tukey's honest significant difference). For phenylalanine, the detritus end-member differed significantly from those of coral and macroalgae, which were in turn significantly different from that of phytoplankton. Finally, all four end-members were significantly different for leucine $\delta^{13} \mathrm{C}$ values.

We used a PCA of the essential AA $\delta^{13} \mathrm{C}$ values to visualize patterns in the multivariate end-member signatures (Fig. 2). The first two principal components (PCs) of the PCA explained $93 \%$ of the total variability in the system $(\mathrm{PC} 1=70, \mathrm{PC} 2=23 \%$; Table 2$)$. The loadings for $\mathrm{PC} 1$ were all negative and of similar magnitude. Isoleucine was the most important loading for PC2, followed

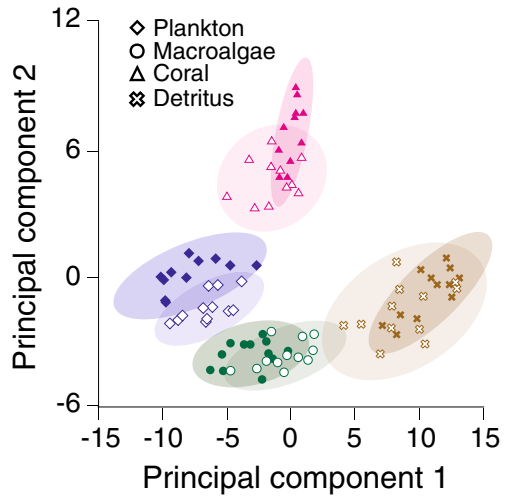

Fig. 2 Multivariate separation of four source end-members on reefs along the Saudi Arabian coast of the Red Sea visualized as principal component 1 and 2 of a principal component analysis of the stable carbon $(\mathrm{C})$ isotope ratio $\left({ }^{13} \mathrm{C}\right)$ values of five essential amino acids (AAs): threonine, isoleucine, valine, phenylalanine, and leucine. Samples were analyzed from shelf reefs (filled symbols) and oceanic reefs (open symbols) and plotted with $95 \%$ confidence ellipses. The four source end-members were: plankton (blue diamonds), macroalgae (green circles), coral (magenta triangles), and detritus (brown squares) (color figure online)

by valine, albeit of opposite sign. The PCA confirmed the relative importance of location and end-members from the univariate ANOVAs above. We found that phytoplankton, 
Table 2 Eigenvectors and variance explained (\%) for the five principal components $(P C)$ in the PC analysis (PCA) of $\delta^{13} \mathrm{C}$ values from end-member (plankton, macroalgae, coral, and detritus) essential AAs on shelf and oceanic reefs near Al-Lith, Saudi Arabia in the Red Sea

\begin{tabular}{lccrrr}
\hline & PC1 & PC2 & PC3 & \multicolumn{1}{c}{ PC4 } & \multicolumn{1}{c}{ PC5 } \\
\hline Threonine & -0.46 & 0.35 & 0.68 & 0.38 & -0.23 \\
Isoleucine & -0.33 & 0.70 & -0.24 & -0.58 & 0.07 \\
Valine & -0.42 & -0.54 & 0.12 & -0.52 & -0.50 \\
Phenylalanine & -0.50 & -0.03 & -0.67 & 0.50 & -0.21 \\
Leucine & -0.50 & -0.31 & 0.11 & -0.03 & 0.80 \\
Variance & 69.5 & 23.1 & 3.9 & 2.5 & 1.1 \\
\hline
\end{tabular}

macroalgae, coral, and detritus were all clearly separated with non-overlapping $95 \%$ density ellipses for almost all end-members from both shelf and oceanic locations in multivariate space (Fig. 2). We detected no obvious effect of location on the multivariate signatures based on the density ellipses for any of the end-members.

We then added essential AA $\delta^{13} \mathrm{C}$ data from the seven fish species to the PCA model with the end-member signatures (Table 3 ) to visualize potential associations between $\mathrm{C}$ end-members at the base of the reef food webs and upper trophic level consumers (Fig. 3). We found good agreement between end-members and their putative consumers. The herbivorous damselfish, S. nigricans, always grouped near the macroalgal end-member, $C$. striatus were grouped with the detritus end-member, and $C$. trifascialis were grouped with the coral end-member. The putative planktivore, $A$. indicus, grouped with the phytoplankton end-member on oceanic reefs; however, individuals on shelf reefs fell between phytoplankton and macroalgae. Individuals from the remaining fish species generally fell in the multivariate space between the end-members, indicating that we had adequately constrained the $\mathrm{C}$ sources at the base of the food web for all of the focal species.

The excellent separation of source end-members in multivariate space, good agreement between essential AA $\delta^{13} \mathrm{C}$ values of end-members and their primary consumers, and the lack of trophic fractionation of essential AAs provided strong justification for the use of an isotope mixing model to quantify the relative contributions of source end-members to reef fish consumers. The Bayesian isotope mixing model revealed significant variability in the relative contributions of source end-members to upper trophic-level consumers (Fig. 4). Variance in model output after 500,000 iterations of the SIAR mixing model was small $(5 \pm 3 \%$; Online Resource 3).

Each of the four source end-members contributed the majority of the $\mathrm{C}$ assimilated by at least one of the seven fish species across the seascape (Fig. 4). C sources for our primary end-member consumers were generally dominated by their putative diet. Detritus, macroalgae, and coral were the dominant source end-members for $C$. striatus (shelf $=76 \pm 8 \%$, oceanic $=70 \pm 10 \%)$, S. nigricans (shelf $=78 \pm 10 \%$, oceanic $=72 \pm 11 \%$ ), and C. trifascialis (shelf $=83 \pm 4 \%$, oceanic $=79 \pm 5 \%$ ), respectively. There was no effect of location on primary $\mathrm{C}$ source contribution for any of the three species (samples pooled across reefs within location, two-sample $t$-test, $p>0.05$ ). Phytoplankton production contributed $57 \pm 7 \%$ to our putative planktivore, A. indicus, on shelf reefs but that proportion increased significantly to $87 \pm 5 \%$ on oceanic reefs (two-sample $t$-test, $t_{38}=-15.49, p<0.0001$ ). Detritus (shelf $=49 \pm 14 \%$, oceanic $=44 \pm 10 \%$ ) and macroalgae (shelf $=36 \pm 16 \%$, oceanic $=34 \pm 12 \%$ ) were both major contributors to the diet of $C$. sordidus, with no significant differences between locations for either $\mathrm{C}$ source. However, C source contributions for both L. ehrenbergii and $G$. javanicus showed significant differences between shelf and oceanic reefs. Macroalgal $\mathrm{C}$ contributed the majority (71 $\pm 13 \%$ ) of the $\mathrm{C}$ to L. ehrenbergii on shelf reefs, but only $17 \pm 10 \%$ on oceanic reefs (two-sample $t$-test, $\left.t_{38}=14.4, p<0.0001\right)$. Phytoplankton was the dominant end-member $(72 \pm 11 \%)$ for L. ehrenbergii on the oceanic reefs. While phytoplankton was the dominant endmember for $G$. javanicus across locations, contributions were significantly higher on oceanic reefs $(79 \pm 9 \%)$ than on shelf reefs $(64 \pm 10 \%)$ (two-sample $t$-test, $t_{38}=-3.66$, $p=0.002$ ).

We used cluster analysis of end-member utilization followed by a constellation plot to visualize patterns of $\mathrm{C}$ flow from source end-members to focal consumers. A $k$-means
Table 3 Eigenvectors and variance explained $(\%)$ for the five PC in the PCA of endmember and fish essential AA $\delta^{13} \mathrm{C}$ values from shelf and oceanic reefs near Al-Lith, Saudi Arabia in the Red Sea; for abbreviations, see Table 2

\begin{tabular}{|c|c|c|c|c|c|c|c|c|c|c|}
\hline & \multicolumn{2}{|l|}{$\mathrm{PC} 1$} & \multicolumn{2}{|l|}{$\mathrm{PC} 2$} & \multicolumn{2}{|l|}{ PC3 } & \multicolumn{2}{|l|}{ PC4 } & \multicolumn{2}{|l|}{ PC5 } \\
\hline & Shelf & Oceanic & Shelf & Oceanic & Shelf & Oceanic & Shelf & Oceanic & Shelf & Oceanic \\
\hline Threonine & 0.56 & 0.44 & -0.39 & 0.50 & -0.68 & -0.74 & 0.25 & 0.06 & 0.11 & 0.07 \\
\hline Isoleucine & 0.38 & 0.24 & -0.63 & 0.57 & 0.56 & 0.57 & -0.35 & 0.54 & 0.17 & -0.01 \\
\hline Valine & 0.41 & 0.45 & 0.55 & -0.58 & 0.16 & -0.04 & 0.06 & 0.54 & 0.70 & 0.40 \\
\hline Phenylalanine & 0.38 & 0.43 & 0.11 & 0.13 & 0.42 & 0.35 & 0.66 & -0.60 & -0.47 & 0.56 \\
\hline Leucine & 0.48 & 0.60 & 0.38 & -0.26 & -0.13 & 0.10 & -0.61 & -0.23 & -0.49 & -0.72 \\
\hline Variance $(\%)$ & 63.3 & 69.9 & 28.0 & 21.9 & 4.4 & 4.1 & 2.9 & 2.5 & 1.5 & 1.4 \\
\hline
\end{tabular}




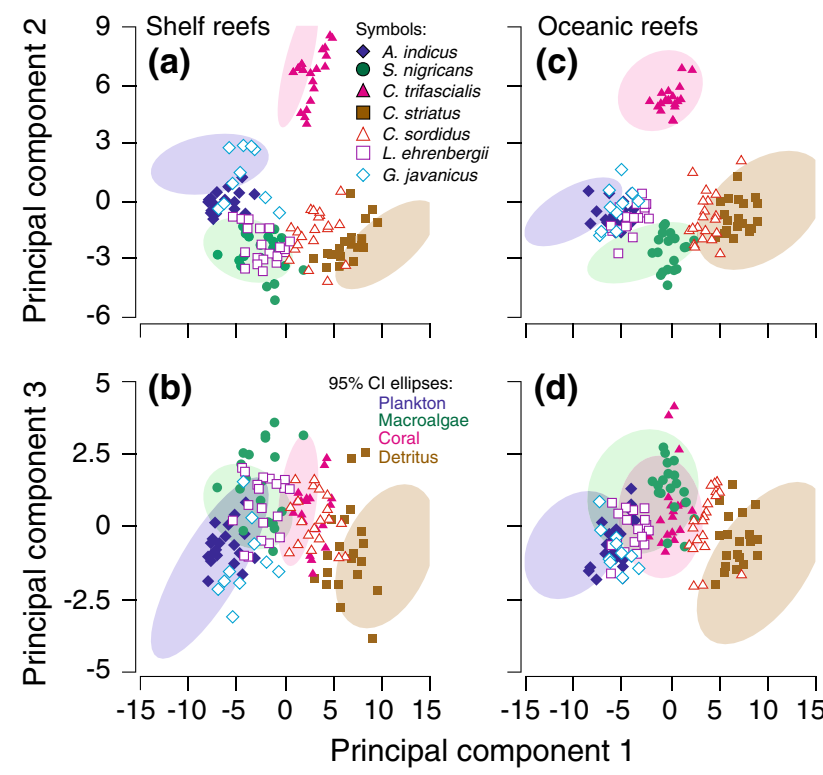

Fig. 3a-d Multivariate separation of seven reef fish species and four source end-members, visualized as the first three principal components of a principal component analysis of the $\delta^{13} \mathrm{C}$ values of five essential AAs: threonine, isoleucine, valine, phenylalanine, and leucine. The four source end-members were plotted as $95 \%$ confidence ellipses as follows: plankton (blue), macroalgae (green), coral (magenta), and detritus (brown). Symbols for primary consumers of each of the four end-members are filled with the same color as the $95 \%$ confidence ellipses of their diet end-member: Amblyglyphidodon indicus (blue diamond), Stegastes nigricans (green circles), Chaetodon trifascialis (magenta triangles) and Ctenochaetus striatus (brown squares). The remaining species (open symbols) were Chlorurus sordidus (red triangles), Lutjanus ehrenbergii (purple squares), and Gymnothorax javanicus (cyan diamonds) $(n=20$ individuals/ species per location except $G$. javanicus where $n=10$ individuals/ location) (color figure online)

cluster analysis identified six clusters as the most parsimonious grouping of multivariate end-member proportions. The resulting constellation plot revealed that each of the individual $\mathrm{C}$ source end-members dominated one of the six clusters (Fig. 5). Cluster A consisted of individuals with high proportions (mean $\pm \mathrm{SD}$ ) of the macroalgal end-member $(75 \pm 9 \%)$, and included $S$. nigricans from both shelf and oceanic reefs as well as $L$. ehrenbergii from shelf reefs. Samples in cluster B contained relatively high proportions of both detritus $(45 \pm 10 \%)$ and macroalgae $(36 \pm 10 \%)$ and were dominated taxonomically by $C$. sordidus, but also contained several individuals of $C$. striatus, L. ehrenbergii, and $S$. nigricans. Cluster $\mathrm{C}$ was composed predominantly of $C$. striatus samples with high proportions of detritus (74 $\pm 8 \%$ ), while cluster D consisted exclusively of $C$. trifascialis individuals and the coral end-member $(75 \pm 9 \%)$. Cluster E contained the phytoplankton end-member $(79 \pm 9 \%)$ and contained a taxonomically diverse representation of A. indicus and L. ehrenbergii samples from oceanic reefs, and G. javanicus samples from both oceanic and shelf locations. Finally, cluster $\mathrm{F}$ consisted almost entirely of $A$. indicus and L. ehrenbergii individuals from shelf reefs that were characterized by approximately equal proportions of phytoplankton $(55 \pm 7 \%)$ and macroalgal $(38 \pm 7 \%)$ end-members.

\section{Discussion}

Identifying important $\mathrm{C}$ sources supporting coral reef food webs remains a significant and ongoing challenge to ocean ecologists (Wyatt et al. 2012b; Hilting et al. 2013; Letourneur et al. 2013). However, the CSIA fingerprinting approach that we outline here has considerable potential to provide a more comprehensive assessment of $\mathrm{C}$ flow through reef food webs than was previously possible. We found excellent separation in the $\delta^{13} \mathrm{C}$ values of essential AAs among four important source end-members (phytoplankton, macroalgae, coral, and detritus) on the study reefs. We were then able to use Bayesian isotope mixing models to determine relative contributions of each of the end-members to a group of reef fishes spanning multiple feeding guilds and trophic positions. The method provided an alternative to conventional dual-isotope ( $\mathrm{C}$ and $\mathrm{N}$ ) approaches that are often under-determined in complex food webs with multiple end-members (Fry 2013; Brett 2014). Moreover, by using essential AAs that exhibit minimal fractionation across trophic levels this method avoids complications of variable and poorly characterized trophic fractionation factors in mixing models (Bond and Diamond 2011). The CSIA fingerprinting approach therefore affords the ability to test hypotheses concerning the response of $\mathrm{C}$ flow through reef food webs to processes including both natural and anthropogenic disturbances and climate change.

We tested the CSIA fingerprinting approach by estimating $\mathrm{C}$ source contributions for several species of coral reef fishes with well-constrained diets. For instance, we estimated that the obligate corralivorous butterflyfish, $C$. trifascialis, received $81 \pm 5 \%$ of its $\mathrm{C}$ from coral-fixed C. Similarly, the farming damselfish, $S$. nigricans, received $75 \pm 11 \%$ of its dietary C from macroalgae. Macroalgae were also important $\mathrm{C}$ sources for a number of other species in our study, including the roaming herbivore (C. sordidus) on oceanic and shelf reefs, and the mesopredator ( $L$. ehrenbergii) and the planktivorous damselfish (A. indicus) on shelf reefs only. Microbially reworked detritus dominated the sources of essential AAs to $C$. striatus, as we predicted. Interestingly, a recent study has suggested that despite its dental morphology, $C$. striatus can remove more algal turf per hour than the common herbivorous grazer Acanthurus nigrofuscus (Marshell and Mumby 2012). We found some support for the functional role of $C$. striatus as an algal grazer, with macroalgae providing an average 
(a) Shelf reefs

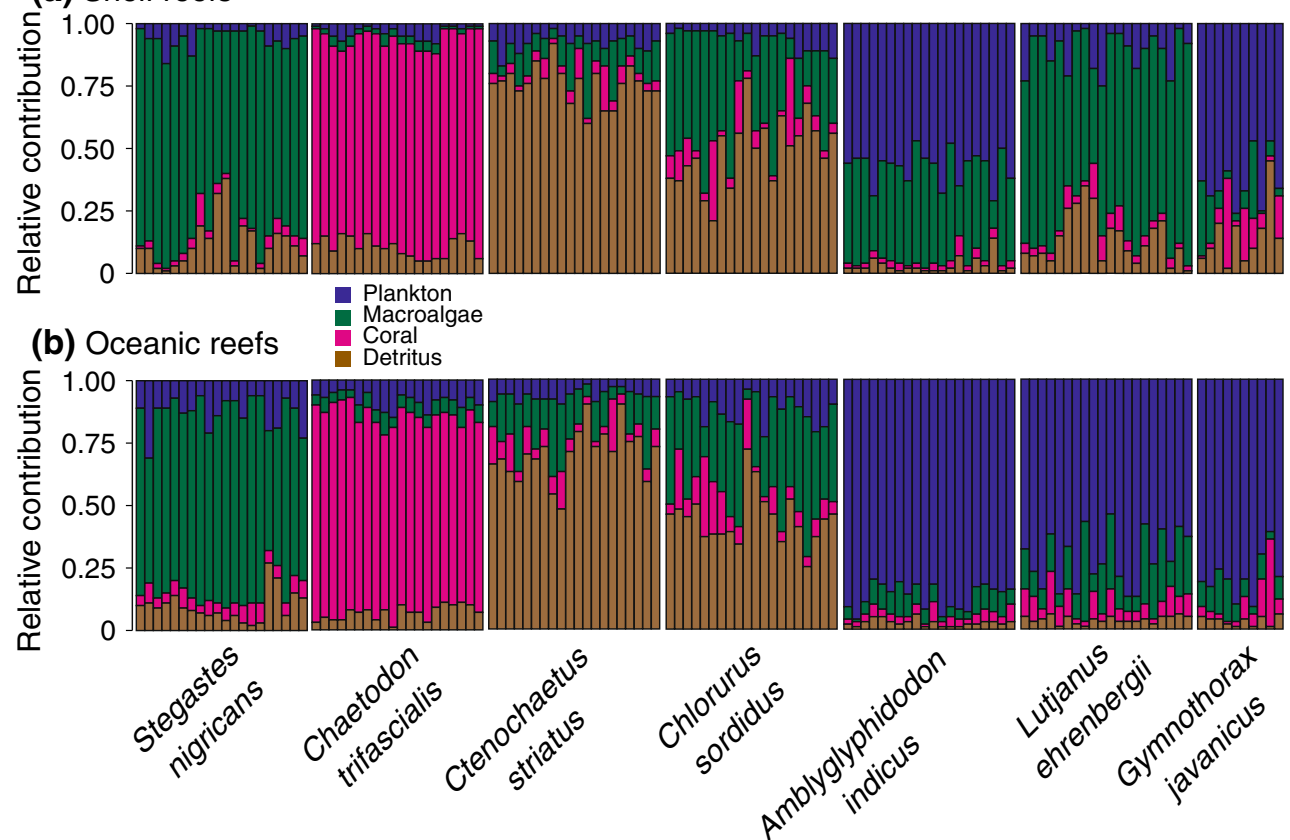

Fig. 4 Relative contributions of four source end-members, plankton (blue), macroalgae (green), coral (magenta), and detritus (brown) to the dietary C supporting seven fish species, Stegastes nigricans, Chaetodon trifascialis, Ctenochaetus striatus, Chlorurus sordidus, Amblyglyphidodon indicus, Lutjanus ehrenbergii, and Gymnothorax javanicus, from a shelf reefs and b oceanic reefs near Al-Lith, Saudi

of $14 \pm 7 \%$ (upwards of $30 \%$ for some individuals) of the $\mathrm{C}$ consumed and assimilated by individuals across the seascape.

Water column primary production represents a significant source of energy and nutrients for coral reefs, as well as an important link between oceanic and reef ecosystems (Emery 1973; Hamner et al. 1988; Richter et al. 2001; Genin et al. 2009). Three of the seven species in our study, the planktivorous damselfish A. indicus, the mesopredator L. ehrenbergii, and the top predator G. javanicus, received significant amounts of $\mathrm{C}$ fixed by phytoplankton $(60 \pm 28 \%)$. Interestingly, two dominantly herbivorous fishes, $C$. sordidus and $S$. nigricans, showed moderate reliance on phytoplankton-based C $(13 \pm 6 \%$, reaching $30 \%$ for some individuals) on oceanic reefs. Previous studies have found that nominal herbivores such as Stegastes spp. assimilated at least some $\mathrm{C}$ from oceanic sources based on bulk SIA (Wyatt et al. 2012b; Letourneur et al. 2013). Both Wyatt et al. (2012b) and Letourneur et al. (2013) hypothesized that the link between the oceanic production signal and herbivores was through changes in nutrient sources supporting macroalgal production associated with oceanographic forcing, such as upwelling of nutrients (Wyatt et al. 2012a). We were able to directly attribute the oceanic production signal in the herbivorous $S$. nigricans and
Arabia in the Red Sea. Relative contributions were determined from the $\delta^{13} \mathrm{C}$ values of five essential AAs (threonine, isoleucine, valine, phenylalanine, and leucine) of end-members and consumers using a Bayesian stable isotope mixing model (bars represent individuals, $n=20$ individuals/species per location except G. javanicus where $n=10$ individuals/location) (color figure online)

C. sordidus in our study to assimilation of phytoplankton production. Herbivores often consume significant numbers of demersal crustaceans that live in benthic reef habitats (Kramer et al. 2013), either incidentally or as a complementary feeding strategy to cope with low protein, plantbased diets (Cruz-Rivera and Hay 2000; Raubenheimer et al. 2009). Many of these crustaceans move up into the water column at night to feed on phytoplankton and particulate organic matter, thereby providing another mechanism for transferring $\mathrm{C}$ fixed in the water column to herbivorous reef fishes. Alternatively, we cannot rule out the possibility that these consumers were feeding on benthic diatoms, as the AA fingerprints of benthic diatoms have not been explicitly tested. Certainly, more detailed studies will be needed to fully resolve the processes that link phytoplankton production with reef food webs.

Detritus represents a major C pool in coral reef systems (Crossman et al. 2001), yet decomposition processes are not well understood as they are generally more diverse and difficult to measure than production processes (Alongi 1988; Moore et al. 2004). The CSIA fingerprinting approach outlined here provides a method for identifying microbial processing of organic material (McCarthy et al. 2004; Larsen et al. 2013), and therefore has the potential to improve our understanding of the role that detrital organic 


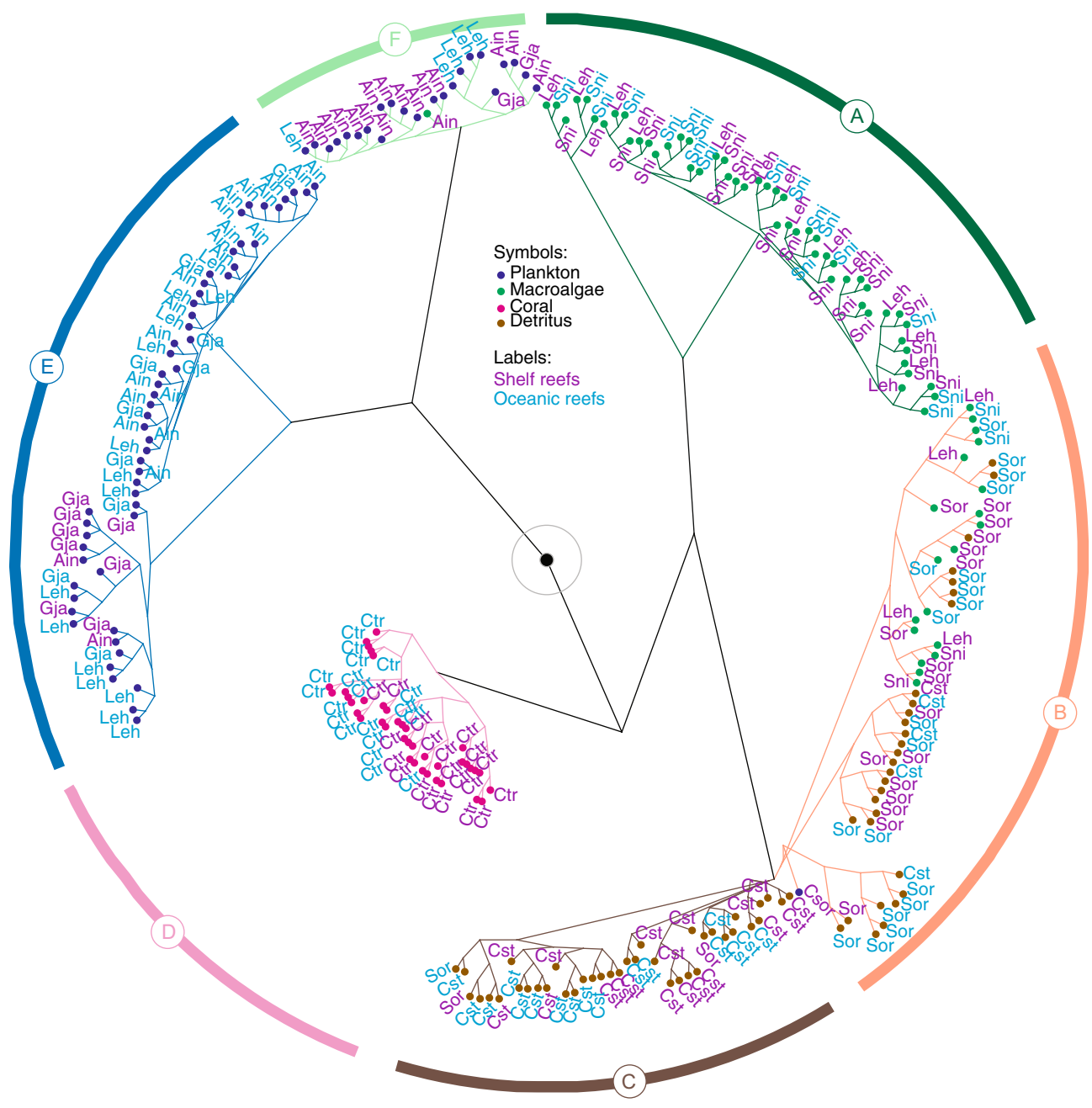

Fig. 5 Constellation plot identifying six clusters (a-f) determined from a $k$-means cluster analysis of the relative contributions of four source end-members to seven coral reef fish species, $S$. nigricans (Sni), A. indicus (Ain), Ctenochaetus striatus (Cst), Chlorurus sordidus (Sor), Chaetodon trifascialis (Ctr), L. ehrenbergii (Leh), and G. javanicus (Gja) collected from shelf reefs (purple labels) and oceanic reefs (cyan labels) along the Saudi Arabian coast of the Red Sea. Points represent individuals $(n=20$ individuals/species per location except $G$. javanicus where $n=10$ individuals/location). Symbol color shows dominant end-member: phytoplankton (blue symbols), macroalgae (green symbols), coral (magenta symbols), and detritus (brown symbols) for each fish sample (color figure online) material plays in coral reef trophic dynamics and productivity. Sampling the detrital end-member, however, is often difficult in reef environments (e.g., Hilting et al. 2013). We used a detritivorous sea cucumber (Moriarty 1982; Uthicke 1999), H. atra, to constrain the isotopic end-member for $\mathrm{C}$ that had been reprocessed by microbial activity through detrital pathways. The essential AA $\delta^{13} \mathrm{C}$ signatures of $H$. atra matched closely to the heterotrophic bacteria endmember of Larsen et al. (2013), suggesting that the sea cucumbers were feeding on a food source that had undergone substantial microbial reworking (Online Resource 4). In addition, our analyses found that detritus was the primary source end-member $(73 \pm 9 \%)$ for the surgeonfish C. striatus across the entire system. Previous work based on dental morphology and feeding observations indicates that $C$. striatus feeds extensively on detritus (Choat et al. 2002, 2004). Taken together, these results suggest that, while a combination of new reef and water column production may have been the original source of organic matter to reef detritus, the essential AA $\delta^{13} \mathrm{C}$ signature of $\mathrm{H}$. atra adequately constrained the isotopic signature of the detrital end-member that is distinct from newly fixed phytoplankton, macroalgae, and coral $\mathrm{C}$.

Detritus was an important source of essential AAs for several focal species, particularly on shelf reefs. For instance, we found that $C$. sordidus received nearly half of its dietary $\mathrm{C}$ from a detrital end-member with the remaining C coming largely from macroalgae. Despite C. sordidus being one of the most abundant coral reef fishes in the Red Sea, its feeding ecology of has been challenging to 
define. Some studies have described $C$. sordidus as a roaming herbivore (Chen 2002; Ledlie et al. 2007; Lecchini and Poignonec 2009), while others have suggested that $C$. sordidus is better described as a detritivore (Choat et al. 2002, 2004). Our results indicated that $C$. sordidus relied on both new reef-derived macroalgal production and microbially reworked detritus, exhibiting significant dietary plasticity at the individual level. Several upper trophic level consumers, including the mesopredator $L$. ehrenbergii and the top predator G. javanicus, received an average of $14 \pm 10 \%$ (reaching $45 \%$ for some individuals) of their dietary $\mathrm{C}$ from detritus on shelf reefs. These results support the findings of a previous study using bacteria-specific fatty acid profiles and bulk SIA that highlighted the importance of detrital organic matter to the production of the mesopredator Lethrinus nebulosus in Australia (Wyatt et al. 2012b). Overall, these results suggest conventional methods of assessing resource utilization of coral reef fishes likely underestimate the importance of microbially recycled $\mathrm{C}$ fueling coral reef food webs.

While all four source end-members contributed to the production of upper trophic level coral reef fishes in our study, we found that a single source end-member often dominated dietary $\mathrm{C}$ assimilation in several focal species. This is perhaps not surprising for primary or even secondary consumers, such as the obligate coralivore $C$. trifascialis, the farming herbivore $S$. nigricans, and the detritivore C. striatus, that are closely linked to their respective endmembers at the base of the food web. It has been far more challenging to determine if upper trophic level consumers are similarly linked to a single source end-member at the base of the food web. Conventional diet and bulk isotope approaches typically require extensive characterization of all dietary linkages within a food web to accurately determine the relative contribution of source end-members to top predators. The AA isotope fingerprinting approach that we used to track $\mathrm{C}$ assimilation patterns, on the other hand, does not require reconstruction of an entire food web to accurately identify baseline $\mathrm{C}$ sources for top predators. We found that high trophic level predators in our study system, L. ehrenbergii and G. javanicus, received the vast majority $(>70 \%)$ of their $\mathrm{C}$ from a single end-member, indicating the presence of tightly linked food chains on coral reefs. This result was surprising given that these predators and their typical prey are all highly mobile generalists with the ability to mix diets across multiple food webs (Sommer et al. 1996; Lieske and Myers (2004). These newly discovered tightly linked food webs open new questions about the resilience of top predators to disturbances at the base of the food web.

We found significant plasticity in $\mathrm{C}$ flow patterns of food webs supporting several species in our system as a function of foraging location within the seascape. For instance, when foraging on shallow reefs on the continental shelf, L. ehrenbergii relied heavily on reef-derived production from macroalgae and detritus $(>85 \%)$. Yet when foraging on oceanic reefs surrounded by deep open water, L. ehrenbergii received the majority of their dietary $\mathrm{C}$ from new water column-based production $(>70 \%)$, with less than $20 \%$ coming from macroalgae and detritus. This pattern of increased reliance on phytoplankton production in oceanic food webs was apparent in several other species as well. The putative planktivore $A$. indicus always relied on water column-based phytoplankton production for the majority of its dietary $\mathrm{C}$; however, individuals residing on shelf reefs also received significant contributions $(37 \pm 10 \%)$ of dietary $\mathrm{C}$ from macroalgal sources. The mix of phytoplankton and algae in the $\operatorname{diet}$ of $A$. indicus on shelf reefs likely reflected higher particulate organic matter loads in the water column of these shallow water shelf reefs, though it is possible that $A$. indicus was directly ingesting macroalgae or macroalgae-consuming invertebrates from the reef surface on the shelf reefs (e.g., Lammens et al. 1985). Yet, as was the case with L. ehrenbergii, $A$. indicus residing on oceanic reefs were dominated by $\mathrm{C}$ from phytoplankton production $(87 \pm 5 \%)$. A similar case was seen in the top predator $G$. javanicus, where the importance of water column-based phytoplankton production was significantly higher on oceanic reefs $(79 \pm 9 \%)$ than it was for individuals on shelf reefs $(64 \pm 10 \%)$. These patterns could not be explained by consumer size, as there were no significant differences in total fish length between individuals collected on shelf and oceanic reefs for any species.

Previous research based on patterns of increasing bulk $\delta^{15} \mathrm{~N}$ values and decreasing $\delta^{13} \mathrm{C}$ values in many coral reef fishes has suggested that the importance of oceanic-derived production to coral reef food webs often increases with proximity to the open ocean, which is perhaps related to the increased access to oceanic nutrients (Wyatt et al. 2012b; Hilting et al. 2013; Letourneur et al. 2013). We directly quantified the increase in the relative contribution of water column-based phytoplankton production to a diverse set of upper trophic level coral reef fishes as a function of reef location within the seascape. However, further research is needed to determine whether the observed increase in reliance on water column production for fishes on oceanic reefs reflected a dietary switch to a more phytoplanktonbased food web or an increase in the flow of phytoplankton $\mathrm{C}$ through the same food webs as on shelf reefs. While our study targeted adult individuals across the entire seascape, previous work has shown that ontogenetic shifts in habitat usage of coral reef fishes can also result in dramatic changes in resource utilization through time and space (Cocheret de la Moriniere et al. 2003; McMahon et al. 2012). 
In conclusion, we found that phytoplankton, macroalgae, coral, and detritus-based $\mathrm{C}$ sources were all important in supporting the production of a diverse suite of fishes on coral reefs of the Red Sea. However, seascape configuration played an important role in structuring the resource utilization patterns of several species in our study, including a numerically dominant planktivore, a commercially important mesopredator, and a piscivorous top predator. Moreover, $\mathrm{C}$ utilization in several upper trophic level consumers was dominated by a single end-member, indicating tight links from a single group of primary producers at the base of a food web to top predators. Further work addressing a larger number of species is needed to more comprehensively understand the flow of $\mathrm{C}$ through entire coral reef food webs. Nonetheless the ability to determine endmember contributions to $\mathrm{C}$ assimilation in reef fishes using CSIA fingerprinting provides a powerful method to develop and test nutritional frameworks for analyzing resource acquisition and allocation. Understanding these trophodynamic interactions is a key to understanding the spatial resilience of complex ecosystems, such as coral reefs.

Acknowledgments This research was based on work supported by Awards USA 00002 and KSA 00011 from King Abdullah University of Science and Technology (KAUST); additional funding was provided by the Woods Hole Oceanographic Institution (WHOI), a KAUST-WHOI award (SPCF-7000000104), and KAUST baseline research funds. We thank E. Mason and the Dream Divers crew for boat and dive operation support, C. Braun for creating the site map, and the following people for field assistance: C. Braun, T. SinclairTaylor, M. Priest, G. Nanninga, N. desRosiers, P. de la Torre, J. Bouwmeester, L.-L. Hamady. We also thank two anonymous reviewers and the handling editor for valuable comments on this paper.

Author contribution statement K. W. M., S. R. T., and M. L. B. conceived of and designed the study; K. W. M. and M. L. B. conducted the fieldwork; K. W. M. and L. A. H. conducted the laboratory analyses; K. W. M. and S. R. T. analyzed the data and wrote the manuscript; M. L. B. and L. A. H. revised and edited the manuscript.

\section{Compliance with ethical standards}

Conflict of interest The authors declare that they have no conflict of interest.

\section{References}

Alongi DDM (1988) Detritus in coral reef ecosystems: fluxes and fates. Proc 6th Int Coral Reef Symp 1:29-36

Arias-Gonzalez JE, Nunez-Lara E, Gonzalez-Salas C, Galzin R (2004) Trophic models for investigation of fishing effect on coral reef. Ecol Model 172:197-212. doi:10.1016/j.ecolmodel.2003.09.007

Arthur KW, Kelez S, Larsen T, Choy CA, Popp BN (2014) Tracing the biosynthetic source of essential amino acids in marine turtles using $\delta^{13} \mathrm{C}$ fingerprints. Ecology 95:1285-1293. doi:10.1890/13-0263.1

Bearhop S, Adams CE, Waldron S, Fuller RA, Macleod H (2004) Determining trophic niche width: a novel approach using stable isotope analysis. J Anim Ecol 73:1007-1012. doi:10.1111/j.0021-8790.2004.00861.x

Berumen ML, Pratchett MS (2008) Trade-offs associated with dietary specialisation for corallivorous butterflyfishes. Behav Ecol Sociobiol 62:989-994. doi:10.1007/s00265-007-0526-8

Bond AL, Diamond AW (2011) Recent Bayesian stable-isotope mixing models are highly sensitive to variation in discrimination factors. Ecol App 21:1017-1023. doi:10.1890/09-2409

Borman A, Wood TR, Black HC, Anderson EG, Oesterling MJ, Womack M, Rose WC (1946) The role of arginine in growth with some observations on the effects of argininic acid. J Biol Chem 166:585-594

Brett MT (2014) Resource polygon geometry predicts Bayesian stable isotope mixing model bias. Mar Ecol Prog Ser 514:1-12. doi:10.3354/meps 11017

Carassou L, Kulbicki M, Nicola TJR, Polunin NVC (2008) Assessment of fish trophic status and relationships by stable isotope data in the coral reef lagoon of New Caledonia, southwest Pacific. Aquat Living Resour 21:1-12. doi:10.1051/alr:2008017

Chen L-S (2002) Post-settlement diet shift of Chlorurus sordidus and Scarus schlegeli (Pisces: Scaridae). Zool Stud 41:47-58

Choat JH, Clements KD, Robbins WD (2002) The trophic status of herbivorous fishes on coral reefs. I. Dietary analyses. Mar Biol 140:613-623. doi:10.1007/s00227-001-0715-3

Choat JH, Robbins WD, Clements KD (2004) The trophic status of herbivorous fishes on coral reefs. II. Food processing modes and trophodynamics. Mar Biol 145:445-454. doi:10.1007/ s00227-004-1341-7

Cocheret de la Moriniere E, Pollux BJA, Nagelkerken I, Hemminga MA, Huiskes AHL, van der Velde G (2003) Ontogenetic dietary changes of coral reef fishes in the mangrove-seagrass-reef continuum: stable isotopes and gut-content analysis. Mar Ecol Prog Ser 246:279-289. doi:10.3354/meps246279

Connell JH (1978) Diversity in tropical rain forests and coral reefs. Science 199:1302-1310

Cote IM, Gill JA, Gardner GA, Watkinson AR (2005) Measuring coral reef decline through meta-analysis. Philos Trans R Soc Lond B 360:385-395. doi:10.1098/rstb.2004.1591

Cowen R (1988) The role of algal symbiosis in reefs through time. Palaios 3:221-227. doi: $10.2307 / 3514532$

Crossman DJ, Choat JH, Clements KD, Hardy T, McConochie J (2001) Detritus as food for grazing fishes on coral reefs. Limnol Oceanogr 46:1596-1605

Cruz-Rivera E, Hay ME (2000) The effects of diet mixing on consumer fitness: macroalgae, epiphytes, and animal matter as food for marine amphipods. Oecologia 123:252-264. doi:10.1007/ s004420051012

Darwin C (1842) The structure and distribution of coral reefs. Appleton, New York

de Goeij JM, van Oevelen D, Vermeij MJ, Osinga R, Middelburg JJ, de Goeij AF, Admiraal W (2013) Surviving in a marine desert: the sponge loop retains resources within coral reefs. Science 342:108-110. doi:10.1126/science.1241981

Deb D (1997) Trophic uncertainty vs. parsimony in food web research. Oikos 78:191-194

Emery A (1973) Comparative ecology and functional osteology of fourteen species of damselfish (Pices: Pomacentridae) at Alligator Reef, Florida Keys. Bull Mar Sci 23:649-770

Ferrier-Pages C, Gattuso JP (1998) Biomass, production and grazing rates of pico- and nanoplankton in coral reef waters (Miyako Island, Japan). Microb Ecol 35:46-57

Fry B (2013) Alternative approaches for solving underdetermined isotope mixing problems. Mar Ecol Prog Ser 472:1-13. doi:10.3354/meps 10168 
Gast GJ, Wiegman S, Wieringa E, Van Duyl FC, Bak RPM (1998) Bacteria in coral reef water types: removal of cells, stimulation of growth and mineralization. Mar Ecol Prog Ser 167:37-45

Genin A, Monismith SG, Reidenbach MA, Yahel G, Koseff JR (2009) Intense benthic grazing of phytoplankton in a coral reef. Limnol Oceanogr 54:938-951. doi:10.4319/lo.2009.54.3.0938

Greenwood NDW, Sweeting CJ, Polunin NVC (2010) Elucidating the trophodynamics of four coral reef fishes of the Solomon Islands using $\delta^{15} \mathrm{~N}$ and $\delta^{13} \mathrm{C}$. Coral Reefs 29:785-792. doi:10.1007/ s00338-010-0626-1

Hallock P, Schlager W (1986) Nutrient excess and demise of coral reefs and carbonate platforms. Palaios 1:389-398

Hamner WM, Jones MS, Carleton JH, Hauri IR, Williams DM (1988) Zooplankton, planktivorous fishes, and water currents on a windward reef face: Great Barrier reef, Australia. Bull Mar Sci 42:459-479

Hare PE, Fogel ML, Stafford TW, Mitchell AD, Hoering TC (1991) The isotopic composition of carbon and nitrogen in individual amino acids isolated from modern and fossil proteins. J Archaeol Sci 18:277-292. doi:10.1016/0305-4403(91)90066-X

Hata H, Kato M (2002) Weeding by the herbivorous damselfish Stegastes nigricans in nearly monocultural algae farms. Mar Ecol Prog Ser 237:227-231. doi:10.3354/meps237227

Hayes JM (2001) Fractionation of the isotopes of carbon and hydrogen in biosynthetic processes. In: Cole DR, Valley JW (eds) Reviews in mineralogy and geochemistry 43, stable isotope geochemistry. The Mineralogical Society of America, Washington, pp 225-277

Hilting AK, Currin CA, Kosaki RK (2013) Evidence for benthic primary production support of a top predator-dominated coral reef food web. Mar Biol 160:1681-1695. doi:10.1007/ s00227-013-2220-X

Howland MR, Corr LT, Young SMM, Jones V, Jim S, van der Merwe NJ, Mitchell AD, Evershed RP (2003) Expression of the dietary isotope signal in the compound-specific $\delta^{13} \mathrm{C}$ values of pig bone lipids and amino acids. Int $\mathrm{J}$ Osteoarchaeol 13:54-65. doi: $10.1002 / 0 a .658$

Hughes TP, Bellwood DR, Connolly SR (2002) Biodiversity hotspots, centres of endemicity, and the conservation of coral reefs. Ecol Lett 5:775-784. doi:10.1046/j.1461-0248.2002.00383.x

Hughes TP, Rodrigues MJ, Bellwood DR, Ceccarelli D, Hoegh-Guldberg O, McCook L, Moltschaniwskyj N, Pratchett MS, Steneck RS, Willis B (2007) Phase shifts, herbivory, and the resilience of coral reefs to climate change. Curr Biol 17:360-365. doi:10.1016/j.cub.2006.12.049

Jim S, Jones V, Ambrose SH, Evershed RP (2006) Quantifying dietary macronutrient sources of carbon for bone collagen biosynthesis using natural abundance stable carbon isotope analysis. Br J Nutr 95:1055-1062. doi:10.1079/BJN20051685

JMP (2013) Graphic builder, version 11. SAS Institute, Cary, NC, URL http://www.jmp.com/software/jmp

Kleppel GS (1993) On the diets of calanoid copepods. Mar Ecol Prog Ser 99:183-195

Kramer MJ, Bellwood O, Bellwood DR (2013) The trophic importance of algal turfs: the crustacean link. Coral Reefs 32:575-583. doi:10.1007/s00338-013-1009-1

Lammens EHRR, de Nie HW, Vijverberg J, van Densen WLT (1985) Resource partitioning and niche shifts of bream (Abramis brama) and eel (Anguilla Anguilla) mediated by predation of smelt (Osmerus eperlanus) on Daphnia hyaline. Can J Fish Aquat Sci 42:1342-1351. doi:10.1139/f85-169

Larsen T, Taylor DL, Leigh MB, O’Brien DM (2009) Stable isotope fingerprinting: a novel method for identifying plant, fungal, or bacterial origins of amino acids. Ecology 90:3526-3535. doi:10.1890/08-1695.1
Larsen T, Ventura M, Andersen N, O'Brien DM, Piatowski U, McCarthy MD (2013) Tracing carbon sources through aquatic and terrestrial food webs using amino acid stable isotope fingerprinting. PLoS One. doi:10.1371/journal.pone.0073441

Larsen T, Bach LT, Salvatteci R, Wang YV, Andersen N, Ventura M, McCarthy MD (2015) Assessing the potential of amino acid $\delta^{13} \mathrm{C}$ patterns as a carbon source tracer in marine sediments: effects of algal growth conditions and sedimentary diagenesis. Biogeosci Discuss 12:1613-1651. doi:10.5194/bgd-12-1613-2015

Lecchini D, Poignonec D (2009) Spatial variability of ontogenetic patterns in habitat associations by coral reef fishes (Moorea lagoon-French Polynesia). Est Coast Shelf Sci 82:553-556. doi:10.1016/j.ecss.2009.01.023

Ledlie MH, Graham NAJ, Bythell JC, Wilson SK, Jennings S, Polunin NVC, Hardcastle J (2007) Phase shifts and the role of herbivory in the resilience of coral reefs. Coral Reefs 26:64116653. doi:10.1007/s00338-007-0230-1

Letourneur Y, Lison De Loma T, Richard P, Harmelin-Vivien ML, Cresson P, Banaru D, Fontaine MF, Gref T, Planes S (2013) Identifying carbon sources and trophic position of coral reef fishes using diet and stable isotope $\left(\delta^{15} \mathrm{~N}\right.$ and $\left.\delta^{13} \mathrm{C}\right)$ analyses in two contrasted bays in Moorea, French Polynesia. Coral Reefs 32:1091-1102. doi:10.1007/s00338-013-1073-6

Lieske E, Myers RF (2004) Coral reef guide: Red Sea. Harper Collins, Oxford

Lindeman RL (1942) The trophic-dynamic aspect of ecology. Ecology 23:399-417. doi:10.2307/1930126

Marshell A, Mumby PJ (2012) Revisiting the functional roles of the surgeonfish Acanthurus nigrofuscus and Ctenochaetus striatus. Coral Reefs 31:1093-1101. doi:10.1007/s00338-012-0931-y

McCarthy DM, Benner R, Lee C, Hedges JL, Fogel ML (2004) Amino acid carbon isotopic fractionation patterns in oceanic dissolved organic matter: an unaltered photoautotrophic source for dissolved organic nitrogen in the ocean? Mar Chem 92:123-134. doi:10.1016/j.marchem.2004.06.021

McMahon KW, Fogel ML, Elsdon T, Thorrold SR (2010) Carbon isotope fractionation of amino acids in fish muscle reflects biosynthesis and isotopic routing from dietary protein. $\mathrm{J}$ Anim Ecol 79:1132-1141. doi:10.1111/j.1365-2656.2010.01722.x

McMahon KW, Fogel ML, Johnson BJ, Houghton LA, Thorrold SR (2011) A new method to reconstruct fish diet and movement patterns from $\delta^{13} \mathrm{C}$ values in otolith amino acids. Can J Fish Aquat Sci 68:1330-1340. doi:10.1139/f2011-070

McMahon KW, Berumen ML, Thorrold SR (2012) Linking habitat mosaics and connectivity in a coral reef seascape. Proc Natl Acad Sci (USA) 109:15372-15376. doi:10.1073/pnas.1206378109

McMahon KW, Hamady L-L, Thorrold SR (2013) Ocean ecogeochemistry: a review. Oceanogr Mar Biol Annu Rev 51:327-374

McMahon KW, Polito M, Abel S, McCarthy MD, Thorrold SR (2015) Carbon and nitrogen isotope fractionation of amino acids in an avian marine predator, the gentoo penguin (Pygoscelis papua). Ecol Evol 5:1278-1290. doi:10.1002/ece3.1437

Moore JC, Berlow EL, Coleman DC, de Ruiter PC, Dong Q, Hastings A, Collins Johnson N, McCann KS, Melville K, Morin PJ, Nadelhoffer K, Rosemond AD, Post DM, Sabo JL, Scow KM, Vanni MJ, Wall DH (2004) Detritus, trophic dynamics and biodiversity. Ecol Lett 7:584-600. doi:10.1111/j.1461-0248.2004.00606.x

Moriarty DJW (1982) Feeding of Holothuria atra and Stichopus chloronotus on bacteria, organic carbon and nitrogen in sediments of the Great Barrier Reef. Austral J Mar Freshwater Res 33:255263. doi:10.1071/MF9820255

Muscatine L (1973) Nutrition of corals. In: Jones OA, Endea R (eds) Biology and geology of coral reefs, vol II. Academic Press, New York, pp 77-115 
Muscatine L, Porter JW (1977) Reef corals: mutualistic symbioses adapted to nutrient-poor conditions. Bioscience 27:454-460. doi: $10.2307 / 1297526$

Odum HT, Odum EP (1955) Trophic structure and productivity of a windward coral reef community on Eniwetok Atoll. Ecol Monogr 25:291-320

Pandolfi JM, Bradbury RH, Sala E, Hughes TP, Bjorndal KA, Cooke RG, McArdle D, McClenachan L, Newman MJH, Paredes G, Warner RR, Jackson JBC (2003) Global trajectories of the longterm decline of coral reef ecosystems. Science 301:955-958. doi:10.1126/science. 1085706

Parnell AC, Inger R, Bearhop S, Jackson AL (2010) Source partitioning using stable isotopes: coping with too much variation. PLoS One 5:e9672. doi:10.1371/journal.pone.0009672

Polovina JJ (1984) Model of a coral reef ecosystem. I. The ECOPATH model and its application to French frigate shoals. Coral Reefs 3:1-11. doi:10.1007/BF00306135

Post DM (2002) Using stable isotopes to estimate trophic position: models, methods, and assumptions. Ecology 83:703-718. doi: $10.2307 / 3071875$

R Development Core Team (2013) R: a language and environment for statistical computing. R Foundation for Statistical Computing, Vienna. ISBN 3-900051-07-0, URL http://www.R-project.org

Raubenheimer D, Simpson SJ, Mayntz D (2009) Nutrition, ecology and nutritional ecology: toward an integrated framework. Funct Ecol 23:4-16. doi:10.1111/j.1365-2435.2009.01522.x

Reeds P (2000) Dispensable and indispensable amino acids for humans. J Nutr 130:1835S-1840S

Richter C, Wunsch M, Rasheed M, Koetter I, Badran MI (2001) Endoscopic exploration of Red Sea coral reefs reveals dense populations of cavity dwelling sponges. Nature 413:726-730. doi:10.1038/35099547

Ryther JH (1969) Relationship of photosynthesis to fish production in the sea. Science 166:72-76. doi:10.1126/science.166.3901.72

Schiff JT, Batista FC, Sherwood OA, Guilderson TP, Hill TM, Ravelo AC, McMahon KW, McCarthy MD (2014) Compound specific amino acid $\delta^{13} \mathrm{C}$ patterns in a deep-sea proteinaceous coral: implications for reconstructing detailed $\delta^{13} \mathrm{C}$ records of exported primary production. Mar Chem 166:82-91

Scott JH, O'Brien DM, Emerson D, Sun H, McDonald GD, Salgado A, Fogel M (2006) An examination of the carbon isotope effects associated with amino acid biosynthesis. Astrobiology 6:867880. doi:10.1089/ast.2006.6.867

Sheppard CRC, Sheppard ALS (1991) Corals and coral communities of Arabia. Fauna Saudi Arabia 12:7-192

Silfer JA, Engel MH, Macko SA, Jumeau EJ (1991) Stable carbon isotope analysis of amino-acid enantiomers by conventional isotope ratio mass spectrometry and combined gas-chromatography isotope ratio mass-spectrometry. Anal Chem 63:370-374. doi:10.1021/ac00004a014

Sommer C, Schneider W, Poutiers JM (1996) FAO species identification field guide for fishery purposes. The living marine resources of Somalia. Food and Agricultural Organization of the United Nations, Rome

Uthicke S (1999) Sediment bioturbation and impact of feeding activity of Holothuria (Halodeima) atra and Stichopus chloronotus, two sediment feeding holothurians, at Lizard Island, Great Barrier Reef. Bull Mar Sci 64:129-141

Ward EJ, Semmens BX, Schindler DE (2010) Including source uncertainty and information in the analysis of stable isotope mixing models. Environ Sci Technol 44:4645-4650. doi:10.1021/ es $100053 \mathrm{v}$

Wild C, Huettel M, Kleute A, Kremb SG, Rasheed MYM, Jorgensen BB (2004) Coral mucus functions as an energy carrier and particle trap in the reef ecosystem. Nature 428:66-70. doi:10.1038/ nature 02344

Wyatt AS, Lowe RJ, Humphries S, Waite AM (2010) Particulate nutrient fluxes over a fringing coral reef: relevant scales of phytoplankton production and mechanisms of supply. Mar Ecol Prog Ser 405:113-130. doi:10.3354/meps08508

Wyatt ASJ, Falter JL, Lowe RJ, Humphries S, Waite AM (2012a) Oceanographic forcing of nutrient uptake and release over a fringing coral reef. Limnol Oceanogr 57:401-419. doi:10.4319/ lo.2012.57.2.0401

Wyatt ASJ, Waite AM, Humphries S (2012b) Stable isotope analysis reveals community-level variation in fish trophodynamics across a fringing coral reef. Coral Reefs 31:1029-1044. doi:10.1007/ s00338-012-0923-y

Wyatt ASJ, Lowe RJ, Humphries S, Waite AM (2013) Particulate nutrient fluxes over a fringing coral reef: source-sink dynamics inferred from carbon to nitrogen ratios and stable isotopes. Limnol Oceanogr 58:409-427. doi:10.4319/lo.2013.58.1.0409 